\title{
食品及び伺料のコリンに関する研究 \\ Studies on the Choline of Foods and Fodders.
}

（第 3 報） 穀類及び種実類のコリン含量について

Part 3. On the Choline Content of Common Japanese Cereals and Seeds.

(昭和 33 年 1 月 16 日受理)

\author{
豊 沢功 \\ (Isao Toyosawa)
}

The determination of choline content in cereals and seeds commonly used in Japan was made from the standpoint of food chemistry. The determination was carried out by the Reineckate method with methanol extraction. The results were as follows:

1) The contents for rice and its bran were 0.4 to 0.8 and 1.0 to $3.2 \mathrm{mg}$ per gram, respectively. The choline loss in rice while polishing ranged from 6 to $43 \%$.

2) The choline content in the bran was found to be the largest in that obtained when rice was polished to $94 \%$ of its weight of others obtained when polished rice mor or less than $94 \%$, and, from this, it seems probable that in the bran layer this is deminantly localized especially in the outer endosperm and aleurone layer.

3) Wheat, barley, and oat contained about $1.0 \mathrm{mg}$ choline per gram, and rye $0.7 \mathrm{mg}$.

4) Corn grown in cold region contained more choline than that in the warm one, and it seems probable that the biosynthesis of choline is affected by temperature.

5) Among the seeds examined, it is also found that the high fat seeds have a tendency to contain larger amount of choline than low ones.

穀䧴及び種垁類中のコリンの量的検討は, 栄養的ばか りでなく, 飼料的にも興味梁いすのと思われるが, 従来 我が国の殼類及び種実類のコリンに関する研究は，2，3 の報告122)を除き，金，白金塩法等に基づく古典的なもの か多く ${ }^{3)}$ ，な他国の研究も比較的一部の款類 (麦, トウ モロコシ等4)51)，豆等(67)に偏し，我が国の実状に適台し ないものが多い。

筆者はさきに若干の油料種実類8)，豆腐及びその副製 品9のコリン量をライネッケ塩法を用いて定量したが, 食品の中でも特に殼類はわれわれの告生活と関係樑いる のであるので, 今回更に同様の方法で, 款類 (米, 麦, 雑殼等）攻び種実類のコリン含量を測定し，2，3 の知見 を得たので,ここに報告する。

\section{実 験 方 法}

コリンの定量は前報9)と同じくメタノール抽出を利用 寸るライネッケ塩法によつた。なお試料は粉砕機で処理

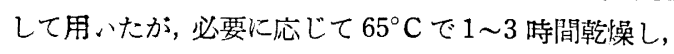
更に海砂と共に微粉化して抽出に供した。

\section{実験結果及び考察}

定量結果は表の通りである。なお表中のコリン含量 $\mathrm{A}$
は新鮮物又は風乾物のコリン含量を, また B 值は絶対乾 物重に換算したコリン含量を示す。

表の結果より次の事が考えられる。

1) 米顔: 米のコリン含量は $1 \mathrm{~g}$ 当り $0.46 \sim 0.83 \mathrm{mg}$. 糠では 1.0 3.2mg. で玄米を精白することにより約 6〜 $43 \%$ のコリンが糠として失われると考えられる。精白 によるコリン損失率にこの様な大差が見られる原因とし $て$, 米の加工処理 (Parboiled rice) により糠層のコリ ンが还乳部に著しく移行するので10), 恐らく品種, 栽培 条件以外に, その眝蔵条件が糠層の各組織におけるコリ ン分布率に変化を与えるるのと考穴られる。

粳米々糯米の精白によるコリン損失率は糯米の方が大 きく, 従つて糯米棣のコリン濃度が幾分高い。

糠では粳米, 糯米と夕一般に $96 \%$ 揚精 (5 分搗米) 及び $92 \%$ 淿精 (精白米) の棣上りも， $94 \%$ 鹪精 (7 分 掹米) の糠にコリンの高い傾向が見られる。精白の際, 5 分搗では玄米の果皮の大半が， 7 分搗では糊粉層の一 部迄，また精白米では糊粉層が完全に棣として除かれ る3)ので, 糠層では外罘孚㤂゙糊粉層にコリンが特に多 く分布していると考えられる。糊粉層は橉脂質態の燐を かなり高濃度に含み, ${ }^{11)}$ また棣の脂質含量は表の如く94 \%のものに比較的多いので, 恐らく糊粉層のコリンは燐 
款類及び種実類のコワン舍量

\begin{tabular}{|c|c|c|c|c|c|c|c|c|c|c|c|c|}
\hline \multirow{2}{*}{ No. } & \multirow{2}{*}{ 品 } & \multirow{2}{*}{ 名 } & \multirow{2}{*}{ 産 } & \multirow{2}{*}{\multicolumn{2}{|c|}{ 地 }} & \multirow{2}{*}{$\begin{array}{c}\text { 水分量 } \\
(\%)\end{array}$} & \multicolumn{2}{|c|}{ コリン含量 $(\mathrm{mg} \mathrm{g})$} & \multirow{2}{*}{ 備 } & \multirow{2}{*}{\multicolumn{3}{|c|}{ 考 }} \\
\hline & & & & & & & A & B & & & & \\
\hline A. 米 & 類： & & - & & & & & & & & & \\
\hline I. & 内地粳米 & & & & & & & & & & & \\
\hline $1 \mathrm{a}$ & 玄 米 & $k(I)$ & 汥 & 阜 & 県 & 15.25 & 0.83 & 0.98 & 1956 年産： & ：水稲 & & \\
\hline $1 \mathrm{~b}$ & 7 分㨶米 & $k(11)$ & & $" \prime$ & & 15.41 & 0.81 & 0.96 & $\prime \prime$ & $\prime \prime$ & & \\
\hline $1 \mathrm{c}$ & 精 白 & k (II) & & $\prime \prime$ & & 15.48 & 0.76 & 0.90 & $\prime \prime$ & $\prime \prime$ & & \\
\hline $2 \mathrm{a}$ & 玄 米 & K (II) & 宮 & 城 & 県 & 15.08 & 0.71 & 0.84 & $\prime \prime$ & $\prime \prime$ & & \\
\hline $\begin{array}{l}2 \mathrm{~b} \\
\text { III. }\end{array}$ & $\begin{array}{l}\text { 精 白 } \text { 米 } \\
\text { 内地糯米 }\end{array}$ & $\begin{array}{l}\text { 米 (II) } \\
\text { *: }\end{array}$ & & $\prime \prime$ & & 15.37 & 0.67 & 0.79 & $\prime \prime$ & $" 1$ & & \\
\hline $3 a$ & 玄 米 & 米 (I) & 群 & 馬 & 県 & 14.81 & 0.81 & 0.95 & 1956 年産 & ：陸稲 & & \\
\hline $3 b$ & 精 白 米 & 米 (II) & & $" 1$ & & 14.98 & 0.46 & 0.54 & $" \prime$ & $\prime \prime$ & & \\
\hline $4 \mathrm{a}$ & 玄 米 & 米 (II) & 宮 & 城 & 県 & 15.35 & 0.63 & 0.74 & $\prime \prime$ & ：水稻 & & \\
\hline $\begin{array}{c}4 \mathrm{~b} \\
\text { III. }\end{array}$ & $\begin{array}{l}\text { 精 白 } \text { 米 } \\
\text { 外 } \text { 米 }\end{array}$ & $\begin{array}{l}\text { 米 ("I) } \\
\text { * : }\end{array}$ & & $\prime \prime$ & & 15.81 & 0.43 & 0.51 & $\prime \prime$ & $\prime \prime$ & & \\
\hline 5 & 精 白 米 & 米 (I) & 台 & & 湾 & 15.00 & 0.60 & 0.71 & 1956 年産 & & & \\
\hline 6 & $" \prime$ & (II) & タ & & 1 & 14.20 & 0.46 & 0.54 & $" \prime$ & & & \\
\hline 7 & $" \prime$ & (III) & $\pi$ & e 1 & ン & 14.75 & 0.74 & 0.87 & $" \prime$ & & & \\
\hline IV. & 棣 类 & 頼： & & & & & & & & & & \\
\hline $8 a$ & 粳米糠 & (96\%搗精- I ) & 岐 & 阜 & 県 & 12.23 & 1.86 & 2.12 & 1956 年産： & 水稲：月 & 脂質含量 & $19.46 \%$ \\
\hline $8 b$ & 11 & $(94 \% \quad \prime \prime)$ & & $\prime \prime$ & & 12.49 & 2.11 & 2.41 & "l & $\prime \prime$ & $"$ & $19.77 \%$ \\
\hline $8 c$ & " & $(92 \% \quad \prime \prime)$ & & $\prime \prime$ & & 12.48 & 1.70 & 1.94 & $\prime \prime$ & $" \prime$ & $\prime \prime$ & $17.51 \%$ \\
\hline $9 \mathrm{a}$ & "I & (96\%搗精-II) & 宮 & 城 & 県 & 12.92 & 0.94 & 1.08 & $\prime \prime$ & $\prime \prime$ & $\prime \prime$ & $21.61 \%$ \\
\hline $9 \mathrm{~b}$ & $" 1$ & $(94 \% \quad " \prime)$ & & $\prime \prime$ & & 12.57 & 1.10 & 1.26 & $\prime \prime$ & $\prime \prime$ & $\prime \prime$ & $23.02 \%$ \\
\hline $9 \mathrm{c}$ & ." & $(92 \% \quad \prime \prime)$ & & $\prime \prime$ & & 12.18 & 1.02 & 1.16 & $\prime \prime$ & $" \prime$ & " & $19.33 \%$ \\
\hline 10 & 糯米糠 & (94\%搗精- I ) & 群 & 馬 & 県 & 11.64 & 3.21 & 3.63 & 1956 年産: & ：陸稲： & $\prime \prime$ & $20.85 \%$ \\
\hline $11 \mathrm{a}$ & $" \prime$ & (96\%搗精- II) & 宮 & 城 & 県 & 13.06 & 2.04 & 2.35 & $\prime \prime$ & ：水稲： & $" \prime$ & $19.23 \%$ \\
\hline $11 \mathrm{~b}$ & $" \prime$ & $(94 \% \quad \|)$ & & $" \prime$ & & 12.52 & 3.02 & 3.45 & $" \prime$ & $" \prime$ & $" \prime$ & $22.99 \%$ \\
\hline $11 \mathrm{c}$ & $" \prime$ & $(92 \% \quad \|)$ & & $\prime \prime$ & & 13.28 & 2.23 & 2.57 & $" \prime$ & $" \prime$ & $" \prime$ & $15.73 \%$ \\
\hline
\end{tabular}

B. 麦 類 :

\begin{tabular}{|c|c|c|c|c|c|c|c|}
\hline 1 & 小麦 (硬 質) (I) & 大阪府立農試 & 14.80 & 0.99 & 1.16 & 1957 年産： & 農林 72 号 \\
\hline 2 & $\| \quad$ (II) & $\prime \prime$ & 14.25 & 1.11 & 1.29 & $" \prime$ & アカッキ \\
\hline 3 & 小麦粉 (全 粒 粉) & 大阪市市販 & 13.18 & 0.97 & 1.12 & & \\
\hline 4 & " (パテント粉) & "I & 12.32 & 0.92 & 1.05 & & \\
\hline 5 & 小麦 フ ス マ & $\prime \prime$ & 11.95 & 1.20 & 1.36 & & \\
\hline 6 & 小 麦 肧 芽 & 大阪府立農試 & 8.21 & 4.32 & 4.71 & 1957 年産： & 農林 72 号 \\
\hline 7 & 裸 表 (硬 質) (I) & $\prime \prime$ & 14.75 & 0.84 & 0.99 & $\prime \prime$ & 大阪白珍子 \\
\hline 8 & $\begin{array}{lll}\prime \prime & \text { (II) }\end{array}$ & $\prime \prime$ & 15.05 & 0.69 & 0.81 & $\prime \prime$ & 大阪奴 52 \\
\hline 9 & $" \prime$ （軟 質） & "I & 14.97 & 0.67 & 0.79 & $\prime \prime$ & 赤神力 \\
\hline 10 & " (押 麦) & 大阪市市販 & 14.42 & 0.69 & 0.81 & & \\
\hline 11 & 大 麦 & 大阪府立農試 & 14.86 & 1.09 & 1.28 & 1957 年産： & 畿内交野：稃なし \\
\hline 12 & " (押 麦) & 大阪市市販 & 14.54 & 1.03 & 1.21 & & \\
\hline 13 & ヒール麦 (二条大麦) & 大阪府立農試 & 14.86 & 1.05 & 1.23 & 1957 年産： & アサヒ 12 号: 稃なし \\
\hline 14 & 燕 麦 & $\begin{array}{l}\text { 大阪府立大 } \\
\text { 農業短 }\end{array}$ & 12.29 & 1.12 & 1.28 & $\|$ & Victory \\
\hline
\end{tabular}


C. 雑 穀 類:

\begin{tabular}{|c|c|c|c|c|c|c|c|}
\hline I . & トウモロコシ： & & & & & & \\
\hline 1 & Dent 種 (I) & 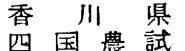 & 13.37 & 0.44 & 0.51 & 1956 年痤： & \\
\hline 2 & $" \prime(" 1)$ & 11 & 13.01 & 0.31 & 0.36 & " & \\
\hline 3 & $" \prime(11)$ & $" \prime$ & 12.10 & 0.58 & 0.66 & $\prime \prime$ & \\
\hline 4 & Pop $\quad " \quad(\|)$ & $\prime \prime$ & 12.37 & 0.17 & 0.19 & $" \prime$ & \\
\hline 5 & Dent $\quad \| \quad$ (II) & $\begin{array}{l}\text { 札 增市 } \\
\text { 北海道農試 }\end{array}$ & 14.22 & 0.50 & 0.58 & $" \prime$ & : Wisconsin 12 号 \\
\hline 6 & Flint $\quad$ (") & 11 & 13.24 & 0.58 & 0.67 & $" \prime$ & : Longfellow \\
\hline 7 & Sweet " (") & $\prime \prime$ & 12.70 & 0.87 & 1.00 & $" \prime$ & : Ever Green \\
\hline II. & ミレット類： & & & & & & \\
\hline $8 \mathrm{a}$ & $\gamma \quad\urcorner$ (全 粒) & 大阪市市販 & 14.67 & 0.78 & 0.91 & 1956 年産 & \\
\hline $8 \mathrm{~b}$ & " （精 白） & $" 1$ & 14.75 & 0.49 & 0.57 & $" 1$ & \\
\hline 9 & キ ビ (全 粒) & $\prime \prime$ & 15.17 & 0.84 & 0.99 & $" 1$ & \\
\hline 10 & $\varepsilon x(\|)$ & $" \prime$ & 14.03 & 0.64 & 0.74 & $\prime \prime$ & \\
\hline 11 & 高 梁 ( $" 1)$ & " & 14.70 & 0.64 & 0.75 & $" \prime$ & \\
\hline
\end{tabular}

D. 種実 類:

\begin{tabular}{|c|c|c|c|c|c|c|c|c|c|c|c|}
\hline 1 & 七 & $\checkmark$ & ワ & $y$ & $\begin{array}{l}\text { 大阪府章 } \\
\text { 大農業短 }\end{array}$ & 8.17 & 2.10 & 2.29 & 1957 年㗧： & : 脂質含量 & $38.91 \%$ \\
\hline 2 & $a^{*}$ & & $\nabla$ & （白） & 大阪府枚方市 & 7.11 & 1.43 & 1.54 & " & "I & $45.37 \%$ \\
\hline 3 & & " & & (黒) & 尘 & 8.16 & 1.22 & 1.33 & 1956 年産： & $" 1$ & $42.65 \%$ \\
\hline $4 \mathrm{a}$ & 落 & 花 生 & （全 & 粒) & $\begin{array}{l}\text { 大阪府 立 } \\
\text { 大農業短大 }\end{array}$ & 7.40 & 1.53 & 1.65 & $" 1$ & $" 1$ & $47.52 \%$ \\
\hline $4 \mathrm{~b}$ & & $" \prime$ & （肧 & 芽) & 叫 & 9.01 & 1.98 & 2.18 & $\prime \prime$ & & \\
\hline $4 \mathrm{c}$ & & $" \prime$ & （涩 & 皮) & " & 15.27 & 0.88 & 1.04 & $\prime \prime$ & & \\
\hline 5 & 七 & & $\nabla$ & & $\prime \prime$ & 5.41 & 0.62 & 0.66 & 1957 年産： & & \\
\hline 6 & $x$ & $\exists$ & $\nabla$ & & 大阪市市販 & 8.40 & 1.17 & 1.28 & 脂質含量 & $40.93 \%$ & \\
\hline 7 & カ & ナリシー & ード & & $" 1$ & 12.58 & 1.23 & 1.41 & $\prime \prime$ & $7.19 \%$ & \\
\hline 8 & 麻 & & 実) & & $" 1$ & 9.65 & 0.95 & 1.05 & & & \\
\hline 9 & 水 & 瓜 種 & 子 & & 奈 良 県 & 11.86 & 0.41 & 0.47 & 1957 年産 & & \\
\hline 10 & $\eta$ & ル & ミ & & 山形 県 & 4.77 & 0.39 & 0.41 & 1956 年産 & & \\
\hline 11 & ク & & y & & 兵 庫 県 & 63.22 & 0.46 & 1.25 & 1957 年産 & & \\
\hline 12 & ギ & ン ナ & ン & & 大阪 市 & 52.07 & 0.41 & 0.86 & " & & \\
\hline 13 & $\eta$ & x & キ & & $\begin{array}{l}\text { 大阪 府 } \\
\text { 河内長野市 }\end{array}$ & 43.50 & 0.28 & 0.50 & $\prime \prime$ & & \\
\hline 14 & + & & ラ & & 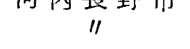 & 17.77 & 0.24 & 0.29 & $\prime \prime$ & & \\
\hline 15 & $\boldsymbol{r}$ & ラ & シ & & 兵庫県宝塚市 & 37.72 & 0.30 & 0.48 & $" \prime$ & & \\
\hline
\end{tabular}

脂質の型で存在するものが多いと思われる。

2）麦類： $1 \mathrm{~g}$ 当りのコリン含量は, 小麦, 大麦, 䜩 麦共に約 $1.0 \mathrm{mg}$, 裸麦は $0.7 \mathrm{mg}$ 前後で従来の6)7)12)13)文 献の值とほぼ一致している。

麦類では小麦肧芽が特に高濃度のコリンを合んでいる が，小麦フスマのコリン量は小麦のそれと殆んど変ら ず，押麦，製粉等の加工によるコリンの損失は比較的少 ないと考えられる。

3）雑款類：トウモロコシでは四国産よりる北海 道 産のものに幾分多くのコリンが含まれていた。成育期間 (5 月 9 月) の平均温度が $20^{\circ} \mathrm{C}$ 以上の暖地に多い $\mathrm{Pop}$ corn のコリン含量が少ないのに対し, $17^{\circ} \mathrm{C}$ 以下が適池 である Sweet corn のコリンが明らかに高值を示して
いるのは興味深い。北米産トウモロコシが $1 \mathrm{~g}$ 当り約 $0.4 \mathrm{mg}$ のコリンを合有しているのに反し，インド南部 (Bengal 及び Vellore 地方) 座のものは全く含んでい ないとの報告もあるので, トウモロコシのコリン合成に は，栽培温度が 1 因子になつているとも考えられる。

4) 種夹類：種 実類では高脂質含量のヒマワリ，ゴ マ，落花生，エゴマ等に比較的多くのコリンが見られた が，莱種，大豆，棉実等8)には及ばない。

落花生では他のビタミンB類に見られる如く，特に然 皮に多くのコリンが分布しているとの傾向は見られなか つた。また堅果類，木の実類は一般にコリンに乏しいよ らである。

以上の款類, 種実類の殆んど大部分は, 先に報告した 
油料盾実に比してコリン含量が少ない。しかし米嬚（特

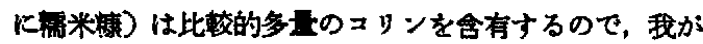
国の食生活から考えて，高度の利用面の研究が有意義と 思われる。今後これらの点について検討する考えであ る。

\section{要 的}

隺類及び種実類のコリン含量を定量し湌討を加えた。

1. 米のコリン合量は $1 \mathrm{~g}$ 当り $0.4 \sim 0.8 \mathrm{mg}$. 糠では $1.0 \sim 3.2 \mathrm{mg}$ で，精白による玄来コッンの損失率は約 6 〜 43\% である。

2. 一般に 7 分揙米の棣のコリン量が高く，綠畨では

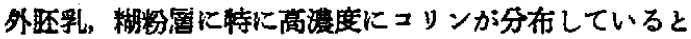

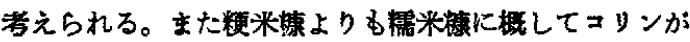
多い。

3. 小考, 大麦, 燕麦は $1 \mathrm{~g}$ 当り約 $1.0 \mathrm{mg}$, 裸麦は $0.7 \mathrm{mg}$ のコリン含量である。また表の一次加工によるコ リンの提失は比较的少ないるのと解されれる。

4.トゥモロコシのコทン含量は概して寒地栽培種〉 䁔地载培種となつており，コリンの生合成には温度か関 与しているるのと推定される。

5. 喠実類で高脂䓄のヒマワリ，ゴマ，落花生，エ エ゙マが比較的高いコリン値を示している。

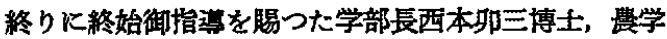
部下村弘数授，また御援助を頂いた古城坤三助教授，中

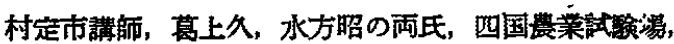
北海道费業試験場，大汳府立農業試験晹盾津分場，並び
に西岡正明，田中猛の両君に深謝致します。

文献

1）小楖達男等： 農化， $26 ， 78 \sim 80$ (1951)

2）小楖逢男, 渡辺順子等：農化東北支部第 7 回膵 演会 (1955)

3）木原芳次郎：教類（雄山閣）(1949）

4) F. A. Robinson: The Vitamin B Complex (Chapman \& Hall Co., London) (1951)

5) The Vitamins, vol. II. (Academic Press Inc.) (1954)

6) H. Chattopadhyay \& S. Banerjee: Food Research, 16, 230 232 (1951)

7) K. Dakshinamurti : Current Science (India), 24, 194 195 (1955)

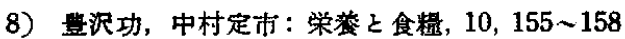
(1957)

9）量沢功：栄養を食糧 10，272 274，(1958）

10) M. C. Kik: J. Agr. \& Food Chem. 3, 600 603 (1955)

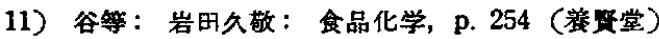
(1955)

12) R. W. Engel: J. Nutrition, 25, $441 \sim 446$ (1943)

13) D. Glick: Cereal Chem., 22, 95 (1945) (大阪府立大学鈸業短期大学部)

\section{グラニユ糖の水分定量法}

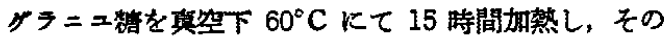
水分を定最する新しい方法で，徉来の实化コバルト法を

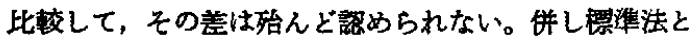
此較すると，棒準法より水分がかなり多く出ている。こ れは主として標海法が結晶外部の水分を測定しているた めと思われる。装置は，オイル㹡散ポンブ，マノメータ 一，D字形トラッブ, 凝縮管, フラスコ, 佰温槽より成 ク，試料はアンプルに詰め，これをフラスコの首の所に
入れ，減圧下にて饻置内部を乾噪後，アンブルを破壊 し，フラスコ中ステンレス整ボールにて磨磼し， $60^{\circ} \mathrm{C}$ 15 洔間加熱，水分を凝维管に捕集した後，D字形トラ ップに集め, 蒸気王, 空温, 試料重量より, 計算式を用 いて，水分会量を計算する。

Determination of water in granulated sugar,

S. Hill and A. G. R. Dobbs: Analyst, 83, 143 (1958) (五十崫) 